\title{
Uterine Junctional Zone Thickness, Cervical Length and Bioelectrical Impedance Analysis of Body Composition in Women with Endometriosis
}

\author{
Selçuk Ayas, Mesut Bayraktar, Ayşe Gürbüz, Akif Alkan, Sadiye Eren \\ Department of Gynecology and Obstetrics, Zeynep Kamil Maternity and Pediatric Research and Training Hospital, Istanbul, Turkey
}

\begin{abstract}
Objective: We aimed to evaluate uterine junctional zone thickness, cervical length and bioelectrical impedance analysis of body composition in women with endometriosis.

Material and Methods: This is a prospective study conducted in a tertiary teaching hospital. A total of 73 patients were included in the study. Endometriosis was surgically diagnosed in 36 patients (study group). The control group included 37 patients. Main outcome measure(s): Bioelectrical impedance analysis was used to measure body composition. Uterine junctional zone thickness and cervical length were measured by transvaginal ultrasonography.

Results: Patients' characteristics (age, gravida, parity, live baby, age of menarche, lengths of menstrual cycle, percentage of patients with dysmenorrhea, positive family history), body mass index $(\mathrm{BMI})\left(\mathrm{kg} / \mathrm{m}^{2}\right)$, amount of body fat $(\mathrm{kg})$, percentage of body fat were not statistically different between the two groups $(p>0.05)$. The length of menstruation and cervical length were longer in women with endometriosis. Similarly, the inner myometrium was
\end{abstract} thicker in women with endometriosis than the control group.

Conclusion: The relation between endometriosis and demographic features such as age, gravida, parity, gravida, BMI, lengths of the menstrual cycle, age of menarche are controversial. Longer cervical length and thicker inner myometrial layer may be important in the etiopathogenesis of endometriosis.

Key Words: Bioelectrical impedance analysis, cervix, endometriosis, inner myometrium

Received: 23.01.2012

Accepted: 28.05.2012

\section{Introduction}

Endometriosis is one of the most common problems encountered in gynaecology. It affects women in the reproductive years, is associated with pelvic pain and infertility and can seriously impair health.

As a result of the growing amount of knowledge about the novel adipose tissue product, adipokines, adipose tissue has become to be considered one of the main endocrine organs in the human body, with effects on reproductive function, and glucose homeostasis, steroid production, the immune system and hematopoesis (1). It has long been known that obesity, especially the distribution of adipose tissue has an important impact on the reproductive system (1). Besides, the association between body mass index (BMI) and endometriosis has also been studied and concluded that women with endometriosis tend to be thinner (2-4). Similarly, it has been argued that the severity of the disease is associated with BMI. Women with advanced-stage endometriosis in the study had lower BMI than those with minimal or mild disease (5).

Although it has been stated that the changes in uterine internal ostium after vaginal parturition play a protective role in the recurrence of endometriosis and dysmenorrheal, the as- sociation between cervical length and endometriosis has not been studied before (6). Similarly, the relation between inner myometrial architectural changes and adenomyosis has been shown, but the inner myometrial changes in women with endometriosis need to be studied (7).

\section{Material and Methods}

\section{Study design}

This study is a prospective study.

\section{Subjects}

From January 2008 through October 2010, patients who underwent surgery (laparoscopy or laparotomy) at the department of obstetrics and gynecology and diagnosed to have endometriosis were included. Ethic committee approval and patients' informed consents were obtained.

Patients were staged according to the American Society for Reproductive Medicine Revised Classification of Endometriosis (8). Patients in the control group were recruited among women who were proved not to have endometriosis by surgery in the same period of time. Indications for surgery for the patients in the control group were unexplained infertility, suspicious tubal patency on hysterosalpingography, 
persistent ovarian cysts, tubal ligation request and ectopic pregnancy. Patients who had uterine reconstructive surgery, uterine mass (for example; myoma uteri), uterine anomalyand immune deficiency were excluded.

Patients' detailed history and measurements were obtained during a planned interview, of which the latest one was two and half months after surgery by the same doctor who knew the patient groups. All measurements were performed between the $4^{\text {th }}$ and $10^{\text {th }}$ days of the menstrual cycle. Inner myometrium and cervical length were carefully measured by using Voluson 730 Expert Ultrasoun Machine (GE Medical Systems Kretz Ultrasound, Software Version 5.0.X, Austria ) and a RIC $5-9 \mathrm{H} \mathrm{mHz}$ transvaginal probe with an empty bladder and patient permission. The inner myometrium was measured from a point near the uterine fundus at a sagital plane while $2 / 3$ of the uterus was placed on the screen. Cervical length was measured at the same magnification from the point of the internal os to the distal end of the cervical canal on screen by using the short-cut mode of the ultrasound. Eight candidate patients for the study group and 1 candidate patient for the control group whose inner myometrium (halo formation) could not be identified were excluded from the study.

Anthropometric measurements (weight, body mass index, percentage of body fat) were performed by using TANITA body composition analyzer BC-420MA (foot to foot) (Japan) with an empty bladder after 8 hours fasting without dehydration. The reliability of bioimpedance analysis in measuring body fat composition has been shown in many studies (9-13).

\section{Statistical analysis}

SPSS for Windows 11.5 (Chi., IL., USA) statistics package program was used for statistical analysis. Descriptive statistics were presented as mean, standard deviation, median, minimum, maximum, frequencies and percentages. The Kolmogorov-Simirnov test was used to determine normal distribution of the continuous data. Continuous variables were analysed with independent samples t test (age, age of menarche, lengths of menstrual cycle, and body mass index) or Mann-Whitney $U$ test (gravida, parity, live baby, percentage of patients with dysmenorrhea, positive family history $\left(1^{\text {st }}\right.$ degree), amount of body fat, percentage of body fat, cervical length, inner myometrium, and the length of menstruation) as appropriate. Pearson chi-square test and Fisher's exact test were used to compare categorical variables. A $p$ value $<0.05$ was considered statistically significant.

\section{Results}

A total of 73 patients were included in the study. All patients in the study group were in advanced stage endometriosis (24 patients with stage 4 and 12 patients with stage 3 ). Patient characteristics are shown in Table 1. The mean of the lengths of the menstrual cycle and the age of menarche in the control group was $29.19 \pm 5.76$ and $13.65 \pm 1.23$ respectively. However, the median of the length of menstruation was statistically different between study and control groups $(p=0.025)$. The percentage of women who have dysmenorrhea was $66.6 \%$ in the study group and $45.9 \%$ in the control group. Endometriosis was present in the family history $\left(1^{\text {st }}\right.$ degree) of $2.77 \%$ of patients in the study group. None of the patients in the control group had a family history of endometriosis (Table 1). Body mass index and percentage of body fat data were not statistically different $(p>0.05)$. Mean BMI was $25.68 \pm 5.34$, and percentage of fat mass $20.78 \%$ in the study group. Mean BMI was $24.37 \pm 3.52$, and percentage of fat mass $23.70 \%$ in control group. The median of the lengths of uterine cervix were statistically different in the groups $(p=0.001)$. The mean cervical length in the study group was $36.30 \pm 8.25 \mathrm{~mm}$, but it was $29.33 \pm 7.11 \mathrm{~mm}$ in the control group. The median inner myometrial thicknesses were statistically different in the groups $(p=0.001)$. The mean inner myometrial thicknesses in the study and in the control group were $5.67 \pm 2.22 \mathrm{~mm}$ and $4.16 \pm 1.92 \mathrm{~mm}$ respectively (Table 2 ).

\section{Discussion}

A study with a large prospective cohort showed that patients with a family history of endometriosis were more likely to have endometriosis. However, the mode of inheritance is still uncertain. It is also stated that the age of menarche and lengths of the menstrual cycle and $\mathrm{BMI}$ are not risk factors for endometriosis and that the risk decreases when regular menses begin after 12-23 months after menarche (14). Similarly, in our study, we could not find a difference in age of menarche and the lengths of the menstrual cycle in the groups with and without endometriosis. However, the median length of menstruation was longer in women with endometriosis. Also the family history was positive in $2.8 \%$ of patients in group with endometriosis.

We have not determined statistically significant differences in the amount of body fat or percentage of body fat by using the Bioelectrical Impedance Analysis between the groups. Mean Body Mass Index of both groups were also not statistically different. In the literature, although we have not encountered any study that searches the relation between endometriosis and the amount of body fat or percentage of body fat by using Bioelectrical Impedance Analysis, it is concluded in a study searching the relation between $\mathrm{BMI}$ and endometriosis that women with advanced-stage endometriosis had lower BMls than those with minimal or mild disease, and BMI was significantly associated with disease severity (15). Likewise, in another study including 32 patients with endometriosis and 52 healthy women, a lower BMI was detected in the study group. It is stated that for every unit increase in BMI, there was an approximate $12-14 \%$ decrease in the likelihood of being diagnosed with endometriosis (16). A more recent study by Vitonis AF et al showed a persistent inverse association between childhood and early adulthood body size and incidence of laparoscopically confirmed endometriosis. This was independent of adult BMI and menstrual cycle characteristics (17). However, our study did not show such a relation in $\mathrm{BMI}$ and advanced staged endometriosis. This might result from ethnic reasons.

Transvaginal ultrasonography is a proper method for measuring the cervical length. Although there are many studies about cervical length in pregnancy in the literature, 
Table 1. Patient characteristics

\begin{tabular}{|c|c|c|c|c|}
\hline Groups & & $\begin{array}{l}\text { Study group } \\
\qquad(n=36)\end{array}$ & $\begin{array}{l}\text { Control group } \\
\qquad(n=37)\end{array}$ & ${ }^{\star} p$ \\
\hline \multirow[t]{2}{*}{$\mathrm{Age}^{\mathrm{a}}$} & Mean \pm SD & $32.39 \pm 5.67$ & $30.54 \pm 5.83$ & 0.175 \\
\hline & Median (Min-Max) & $31(18-42)$ & $30(20-42)$ & \\
\hline \multirow[t]{2}{*}{ Gravidab } & Mean \pm SD & $1.17 \pm 1.13$ & $1.76 \pm 1.92$ & \\
\hline & Median (Min-Max) & $1(0-4)$ & $1(0-7)$ & 0.361 \\
\hline \multirow[t]{2}{*}{ Parity ${ }^{b}$} & Mean士SD & $1 \pm 0.98$ & $0.86 \pm 1.08$ & \\
\hline & Median (Min-Max) & $1(0-3)$ & $1(0-4)$ & 0.411 \\
\hline \multirow[t]{2}{*}{ Live baby ${ }^{b}$} & Mean $\pm S D$ & $1 \pm 0.98$ & $0.81 \pm 1.02$ & \\
\hline & Median (Min-Max) & $1(0-3)$ & $0 .(0-3)$ & 0.323 \\
\hline \multirow[t]{2}{*}{ Age of menarche ${ }^{a}$} & Mean \pm SD & $13.81 \pm 1.3$ & $13.65 \pm 1.23$ & 0.605 \\
\hline & Median (Min-Max) & $14(11-17)$ & $13(12-16)$ & \\
\hline \multirow[t]{2}{*}{ Length of menstruation ${ }^{b}$} & Mean \pm SD & $5.97 \pm 2.21$ & $5 \pm 1.97$ & \\
\hline & Median (Min-Max) & $6(1-15)$ & $5(2-11)$ & $0.025 \dagger$ \\
\hline \multirow[t]{2}{*}{ Length of menstrual cycle } & Mean \pm SD & $28.11 \pm 6.20$ & $29.19 \pm 5.76$ & 0.444 \\
\hline & Median (Min-Max) & $28(17-60)$ & $28(20-60)$ & \\
\hline Patients with dysmenorrhea ${ }^{c}$ & $(\%)$ & $(24 / 36) 66.6 \%$ & $(14 / 37) 45.9 \%$ & 0.100 \\
\hline Positive family history ${ }^{c}$ & $(\%)$ & $(1 / 36) 2.77 \%$ & $(0 / 37) 0.00 \%$ & 0.493 \\
\hline $\begin{array}{l}{ }^{*} \text { - } \text {-values of the independent sar } \\
\text { †There is a significant difference } \\
\text { a Values are expressed as mean } \pm \text { s } \\
\text { bValues are expressed as median } \\
\text { 'Values are expressed as number } \\
\text { SD: standard deviation }\end{array}$ & $\begin{array}{l}\text { t test or Mann-Whitne) } \\
\text { een groups. } \\
\text { ard deviation } \\
\text { imum-maximum) } \\
\text { percentages }\end{array}$ & propriate. & & \\
\hline
\end{tabular}

Table 2. Comparison of Body Mass Index, amount of body fat, percentage of body fat, cervical length and thickness of inner myometrium in study and control group

\begin{tabular}{|c|c|c|c|c|}
\hline Groups & & $\begin{array}{l}\text { Study group } \\
\qquad(n=36)\end{array}$ & $\begin{array}{l}\text { Control group } \\
\qquad(n=37)\end{array}$ & ${ }^{\star} p$ \\
\hline \multirow{2}{*}{ BMI $\left(\mathrm{kg} / \mathrm{m}^{2}\right)^{\mathrm{a}}$} & Mean \pm SD & $25.68 \pm 5.34$ & $24.37 \pm 3.52$ & 0.218 \\
\hline & Median (Min-Max) & $25.20(16.7-36.9)$ & $23.70(18.5-33)$ & \\
\hline \multirow[t]{2}{*}{ Cervical length $(\mathrm{mm})^{\mathrm{b}}$} & Mean $\pm S D$ & $36.30 \pm 8.25$ & $29.33 \pm 7.11$ & \\
\hline & Median (Min-Max) & $35.45(17.2-54.1)$ & $28.20(17.6-43)$ & $0.001 \dagger$ \\
\hline \multirow[t]{2}{*}{ Inner myometrium $(\mathrm{mm})^{\mathrm{b}}$} & Mean \pm SD & $5.67 \pm 2.22$ & $4.16 \pm 1.92$ & \\
\hline & Median (Min-Max) & $5.30(1.6-11.6)$ & $4(1.4-11)$ & $0.001 \dagger$ \\
\hline \multirow[t]{2}{*}{ Amount of body fat $(\mathrm{kg})^{\mathrm{b}}$} & Mean $\pm S D$ & $29.95 \pm 8.02$ & $26.87 \pm 7.55$ & \\
\hline & Median (Min-Max) & $29.90(10.6-43.3)$ & $28.50(9.9-39.6)$ & 0.141 \\
\hline \multirow[t]{2}{*}{ Percentage of body fat $(\%)^{b}$} & Mean \pm SD & $20.78 \pm 9.19$ & $17.35 \pm 7.1$ & \\
\hline & Median (Min-Max) & $18.70(4.7-41.4)$ & $18.40(3.9-31.3)$ & 0.184 \\
\hline \multicolumn{5}{|c|}{$\begin{array}{l}\text { * } \mathrm{p} \text {-values of the independent samples } \mathrm{t} \text { test or Mann-Whitney } \mathrm{U} \text { test as appropriate } \\
\dagger \text { There is a significant difference between groups. } \\
\text { aValues are expressed as mean } \pm \text { standard deviation } \\
\text { bValues are expressed as median (minimum-maximum) }\end{array}$} \\
\hline
\end{tabular}

we could not find a study related to cervical length in nonpregnant women with endometriosis. In our study, mean cervical length in the study group $(36.30 \pm 8.25 \mathrm{~mm})$ was longer than in the control group $(29.33 \pm 7.11 \mathrm{~mm})$. Similarly median cervical length was longer in the study group and this was also statistically significant between both groups. We think that this difference may potentiate retrograde menstruation and/or inner myometrial dyssynergia that may 
have a possible role in the etiopathogenesis of endometriosis.

The shown relation between inner myometrial architectural changes and adenomyosis can also be present between endometriosis and inner myometrium because endometriosis and adenomyosis result from the same physiological mechanism of "tissue injury and repair" involving local estrogen production in an estrogen-sensitive environment normally controlled by the ovary $(7,18)$.

In the literature there is evidence that support the possible role of uterine junctional zone dysfunction in subfertility and etiopathogenesis of endometriosis (19-21). Dysperistaltism was also proposed to be responsible for the higher incidence of endometriosis in patients with a septate uterus in another study (22). Inner myometrial thickness of $\leq 5 \mathrm{~mm}$ is accepted as normal (23). In our control group, the mean inner myometrial thickness was $4.16 \pm 1.92 \mathrm{~mm}$ which was consistent with the literature. We think that statistically higher inner myometrial thickness in our study group could be related to inner myometrial hyperplasia or dysperistaltism that may have a role in developing endometriosis.

\section{Conclusion}

The relation between endometriosis and demographic features such as age, gravida, parity, gravida, BMI, lengths of the menstrual cycle and age of menarche are controversial. Longer cervical length and thicker inner myometrial layer may be important in the etiopathogenesis of endometriosis.

\section{Acknowledgements}

We would like to thank our dear colleague Doctor Selim Kılıç a member of the Clinic Department of Epidemiology and Public Health, Ankara Gülhane Military Medical School for lending a helping hand in the statistical analysis of this study. Authors also thank to Dr. İsmet Gün, from the Department of Obstetrics and Gynecology, GATA Haydarpasa Training Hospital, for his help in the study.

\section{Conflict of Interest}

No conflict of interest was declared by the authors.

\section{References}

1. Bohler HJ, Mokshagundam S, Winters S. Adipose tissue and reproduction in women. Fertil Steril 2010;94:795-825. [CrossRef]

2. Ferrero $S$, Anserini $P$, Remorgida $V$, Ragni N. Body mass index in endometriosis. Eur J Obstet Gynecol Reprod Biol 2005;121:94-8. [CrossRef]

3. Hediger $M$, Hartnett $H$, Louis $G$. Association of endometriosis with body size and figure. Fertil Steril 2005;84:1366-74. [CrossRef]

4. McCann S, Freudenheim J, Darrow S, Batt R, Zielezny M. Endometriosis and body fat distribution. Obstet Gynecol 1993;82:545-9. [CrossRef]
5. Yi K, Shin J, Park M, Kim T, Kim S, Hur J. Association of body mass index with severity of endometriosis in Korean women. Int J Gynaecol Obstet 2009;105:39-42. [CrossRef]

6. Bulletti C, Montini A, Setti P, Palagiano A, Ubaldi F, Borini A. Vaginal parturition decreases recurrence of endometriosis. Fertil Steril 2010;94:850-5. [CrossRef]

7. Brosens JJ, Barker FG, de Souza NM. Myometrial zonal differentiation and uterine junctional zone hyperplasia in the non-pregnant uterus. Hum Reprod Update 1998;4:496-502. [CrossRef]

8. Revised American Society for Reproductive Medicine classification of endometriosis: 1996. Fertil Steril 1997;67:817-21. [CrossRef]

9. Nunez C, Gallagher D, Visser M, Pi-Sunyer FX, Wang Z, Heymsfield SB. Bioimpedance analysis: evaluation of leg-to-leg system based on pressure contact foot-pad electrodes. Med Sci Sports Exerc 1997;29:524-31. [CrossRef]

10. Utter AC, Nieman DC, Ward AN, Butterworth DE. Use of leg-toleg bioelectrical impedance method in assessing body-composition change in obese women. Am J Clin Nutr 1999;69:603-7.

11. Jebb SA, Cole TJ, Doman D, Murgatroyd PR, Prentice AM. Evaluation of the novel Tanita body-fat analyser to measure body composition by comparison with a four-compartment model. $\mathrm{Br} \mathrm{J}$ Nutr 2000;83:115-22.

12. Kushner RF, Roxe DM. Bipedal bioelectrical impedance analysis reproducibly estimates total body water in hemodialysis patients. Am J Kidney Dis 2002;39:154-9. [CrossRef]

13. Sung RY, Lau P, Yu CW, Lam PK, Nelson EA. Measurement of body fat using leg to leg bioimpedance. Arch Dis Child 2001;85:263-7. [CrossRef]

14. Templeman C, Marshall S, Ursin G, Horn-Ross P, Clarke C, Allen $\mathrm{M}$, et al. Adenomyosis and endometriosis in the California Teachers Study. Fertil Steril 2008;90:415-24. [CrossRef]

15. Yi KW, Shin JH, Park MS, Kim T, Kim SH, Hur JY. Association of body mass index with severity of endometriosis in Korean women. Int J Gynaecol Obstet 2009;105:39-42. [CrossRef]

16. Hediger ML, Hartnett HJ, Louis GM. Association of endometriosis with body size and figure. Fertil Steril 2005;84:1366-74. [CrossRef]

17. Vitonis $A F$, Baer HJ, Hankinson SE, Laufer MR, Missmer SA. A prospective study of body size during childhood and early adulthood and the incidence of endometriosis. Hum Reprod 2010;25:1325-34. [CrossRef]

18. Leyendecker G, Wildt L, Mall G. The pathophysiology of endometriosis and adenomyosis: tissue injury and repair. Arch Gynecol Obstet 2009;280:529-38. [CrossRef]

19. Salamanca A, Beltran E. Subendometrial contractility in menstrual phase visualized by transvaginal sonography in patients with endometriosis. Fertil Steril 1995;64:193-5.

20. Leyendecker G, Kunz G, Wildt L, Beil D, Deininger $H$. Uterine hyperperistalsis and dysperistalsis as dysfunctions of the mechanism of rapid sperm transport in patients with endometriosis and infertility. Hum Reprod 1996;11:1542-51. [CrossRef]

21. IJland MM, Evers JL, Dunselman GA, Volovics L, Hoogland HJ. Relation between endometrial wavelike activity and fecundability in spontaneous cycles. Fertil Steril 1997;67:492-6. [CrossRef]

22. Nawroth F, Rahimi G, Nawroth C, Foth D, Ludwig M, Schmidt T. Is there an association between septate uterus and endometriosis? Hum Reprod 2006;21:542-4. [CrossRef]

23. Mark AS, Hricak $H$, Heinrichs LW, Hendrickson MR, Winkler ML, Bachica JA, et al. Adenomyosis and leiomyoma: differential diagnosis with MR imaging. Radiology 1987;163:527-9. 